\title{
The Ninth Consortium on Revolutionary Europe
}

The Consortium had a very full and exciting program at its spring 1979 meeting in Charleston, South Carolina. There were three plenary sessions and eleven individual sessions covering a variety of aspects of European history in the age of revolutions, 1780-1848. Although the history of revolutionary France predominated numerically, there were sessions on Italy and Hungary in 1848 and comparative sessions on the military, the police, intellectual currents, and the use of symbols in the process of legitimation. This comparative approach and the more general European coverage are the great strengths of the Consortium.

The special session on the final morning was in many ways the highlight of the meeting. Elizabeth Eisenstein moderated a symposium on "Caste, Class, Elites, and Revolution," in which short papers were presented by Robert Forster, Elizabeth Fox-Genovese, Simon Schama, and M.J. Sydenham with George Taylor serving as general commentator. For the most part, these were provocative and stimulating papers, and anyone interested in the history of the French Revolution should look forward to the publication of the Proceedings (which can be ordered from Professor Warren F. Spencer, History Department, The University of Georgia, Athens, Ga. 30602). The statements of position, though brief, added up to a tantalizing overview of the diverse perspectives operating in Revolutionary historiography in the Anglo-Saxon world. Robert Forster led off with a discussion in the long-term of the emergence of a society of notables as a result of the Revolution. Landlords and bureaucrats came together in this "class" of notables who dominated a new hierarchy based on utilitarian criteria. Fox-Genovese argued for (what seemed to this observer at least) a neo-Marxist analysis of the Revolution, in which the state is taken as seriously as competing modes of production. In her view, the Revolution began as a crisis of the state which in turn threatened the whole system of social relationships. The Revolution made possible the creation of a new state and with it a new social system; in short, the Revolution laid the foundations of bourgeois society, which can be seen, for example, in the articulation of a new vision of domestic space (her own current research interest). Simon Schama focused attention on the Revolution and the revolutionaries rather than on the results of the event. In a fascinating presentation he discussed the importance of style, rhetoric, language, and political manners and argued that the revolutionaries had a theatrical self-consciousness. Michael Sydenham, in his paper on the federalist revolt, seemed to argue that the Revolution cannot be forced into artificial, ideological categories.

Faced with the rather formidable task of putting these various presentations together, George Taylor launched a lively, sometimes heated discussion with controversial assertion that the panelists had written the obituary for the classstruggle thesis of the Revolution. What was most striking about the ensuing discussion was just how potent Marxism still is: though the reactions to Taylor's remarks and to the presentations in general varied enormously, it was evident 
that the debates about the role and meaning of the Revolution have not ended, and that the question of class is still open. But it also became apparent in the discussion that Anglo-Saxon historiography of this period has not always been well-informed about the theoretical issues. Too often the argument has been a "dialogue des sourds" with "vulgar" empiricists taking on "vulgar" Marxists. The presentations showed that it is possible to get beyond that stage of argument by directing research to questions that will throw light on the more general issues.

Lynn A. Hunt

University of California, Berkeley

\section{Labour/Le Travailleur}

\section{Contents-Spring 1980}

Allen Mills-Single Tax, Socialism and the Independent Labour Party of Manitoba: The Political Ideas of F.J. Dixon and S.J. Farmer

Wallace Clement-The Subordination of Labour in Canadian Mining

W.J.C. Cherwinski-The Incredible Harvest Excursion of 1908

Allen Seager-Minto, New Brunswick: A Study in Canadian Class Relations Between the Wars

Jerry Lembcke-The IWA in British Columbia, 1942-1951

Gene Howard Homel-Fading Beams of the Nineteenth Century: Radicalism and Early Socialism in Canada's 1890s

David Sutherland-The Stanyan Ropeworks of Halifax, Nova Scotia: Glimpses of a Pre-industrial Manufactory

Plus: conference reports, book reviews and abstracts.

Available, for $\$ 10.00$ per year (Spring and Fall), through:

G. Kealey

Labour/Le Travailleur

Department of History

Dalhousie University

Halifax, Nova Scotia

Canada B3H 355 